\title{
Nutritional status and other predictors of immune response recovery among HIV-AIDS patients receiving antiretroviral therapy in Dr. Sardjito Hospital, Yogyakarta, Indonesia: a retrospective cohort study
}

\author{
Ika Puspita Asturiningtyas ${ }^{1,2^{*}}$, Yanri Wijayanti Subronto ${ }^{3}$ \& Nur Aini \\ Kusmayanti ${ }^{4}$
}

${ }^{1}$ Magelang Unit for Health Research and Development, National Institute of Health Research and Development, Ministry of Health of Indonesia, Magelang, Central Java, Indonesia; ${ }^{2}$ Field Epidemiology Training Program, Faculty of Medicine, Public Health and Nursing, Universitas Gadjah Mada, Yogyakarta, Indonesia; ${ }^{3}$ Faculty of Medicine, Public Health and Nursing, Universitas Gadjah Mada, Yogyakarta, Indonesia; ${ }^{4}$ Center for Tropical Medicine, Universitas Gadjah Mada, Yogyakarta, Indonesia

\begin{abstract}
Introduction: Nutritional status and immune response of Human Immunodeficiency Virus-Acquired Immune Deficiency Syndrome (HIV-AIDS) patients are closely connected. There are limited studies assessing the influence of Body Mass Index (BMI) on immune response recovery among HIV patients in Indonesia. This study aimed to identify the BMI and other predictors of immune response recovery among HIV-AIDS patients following two years of Antiretroviral (ARV) therapy. Methods: This research was a retrospective cohort study among HIV-AIDS patients who started ARV therapy from January 2014 to December 2016 at Dr. Sardjito Hospital, Yogyakarta. Data were collected from ARV registry and medical reports. Data were analysed using linear regression. Results: A total of 255 patients were included in the study, with a median BMI of $20.07 \mathrm{~kg} / \mathrm{m}^{2}$. Results showed that BMI was not significantly correlated with immune response recovery at the 6th, 12th, 18th, and 24 th months of ARV therapy ( $p>0.05)$. But, the increase in cluster of differentiation 4 (CD4) cell count was higher in overweight and pre-obese patients than underweight patients, especially in the 18th and 24th months of therapy. Factors related to immune response recovery were the regularity of treatment at the 12 th, 18th, and 24th months of ARV therapy, and the use of Tenofovir at 18th-month therapy $(p<0.05)$. Conclusion: Immune response recovery was higher in overweight and pre-obese patients. Using Tenofovir type ARV and doing treatment regularly can increase CD4 cell counts. Underweight patients need to enhance their nutritional status to improve their immune response during ARV therapy.
\end{abstract}

Keywords: Nutritional status, body mass index, human immunodeficiency virus, immune response, CD4

\footnotetext{
*Corresponding author: Ika Puspita Asturiningtyas Magelang Unit for Health Research and Development, National Institute of Health Research and Development, Ministry of Health of Indonesia Kavling Jayan, Borobudur, Magelang, Central Java, 56553

Tel: (+62)293-789435; Fax: (+62)293)-788460; E-mail: ikapuspita8845@yahoo.com doi: https://doi.org/10.31246/mjn-2020-0018
} 


\section{INTRODUCTION}

Nutritional status and immune cell function are interrelated. The review conducted by Alwarawah, Kiernan \& Maclver (2018) underlined the effects of nutrition on immune cells. T cells are the main component of the immune system that regulate all immune responses in the body. $T$ cells are very sensitive to nutritional deficiencies or excesses, so the immunity of individuals who experience undernutrition and excess nutrition also needs to be understood (Alwarawrah et al., 2018).

Human Immunodeficiency Virus (HIV) is a virus attacking the immune cells, particularly cluster of differentiation 4 (CD4) cells, a part of $\mathrm{T}$ cells, causing decreased number of CD4 cells and loss of immunity, leading to susceptibility towards infection by pathogenic microorganisms and other opportunistic infections (MakvandiNejad, 2016). Antiretroviral (ARV) therapy is used to slow the progression of HIV infection and reduce mortality. ARV therapy can control virus replication and improve immune response by increasing the number of CD4 cell counts. Research showed that ARV therapy would increase CD4 cell counts of patients with HIVAIDS (Dravid et al., 2011; Walker \& Mcmichael, 2012).

There are some researches which studied about the factors influencing immune response recovery of HIV patients following ARV therapy. Nutritional status is one factor that needs to be considered. The interaction between immune response and nutritional status in HIV infected people is complex and interrelated. HIV infection can cause malnutrition through opportunistic infections, failure of food absorption, and also anorexia. On the other hand, malnutrition in HIV infected people will accelerate the progression of HIV into Acquired Immune Deficiency Syndrome
(AIDS). Both malnutrition and HIV can decrease the number of CD4 cell counts (Duggal, Chugh \& Duggal, 2012).

Body Mass Index (BMI), which is a measure for indicating nutritional status in adults, has a strong relationship with immune response. In a recent study, underweight women with ARV therapy had twice a higher risk of mortality compared to normal weight women (Sharma et al., 2015). The increase in CD4 cell counts after 12 months of ARV therapy was found to be greater in patients with an initial BMI of 25$30 \mathrm{~kg} / \mathrm{m}^{2}$ ( $\left.p=0.03\right)$ (Koethe et al., 2011). Therefore, it is necessary to evaluate the effect of nutritional status at the initiation of ARV therapy on the immune response recovery of HIV-AIDS patients. This study aimed to identify the BMI and other predictors of immune response recovery among HIV-AIDS patients following two years of ARV therapy.

\section{MATERIALS AND METHODS}

\section{Study design and participants}

This study was a retrospective cohort study at Dr. Sardjito Hospital, Yogyakarta, one of the first national hospitals that conducted ARV therapy in Central Java and Yogyakarta. The hospital also provides comprehensive HIV-related services.

This study evaluated the relation between nutritional status and other factors at the first time of ARV with immune response recovery following two years of ARV therapy. Nutritional status was measured based on BMI status. Immune response recovery was marked by the changes in CD4 cell count at 6th, 12 th, 18th, and 24th months of ARV therapy. CD4 cell count changes were calculated from the reduction of $\mathrm{CD} 4$ cell count at 6 th, 12 th, 18 th, and 24 th months of ARV therapy from CD4 cell count at the first time of ARV therapy.

The subjects of this study were 


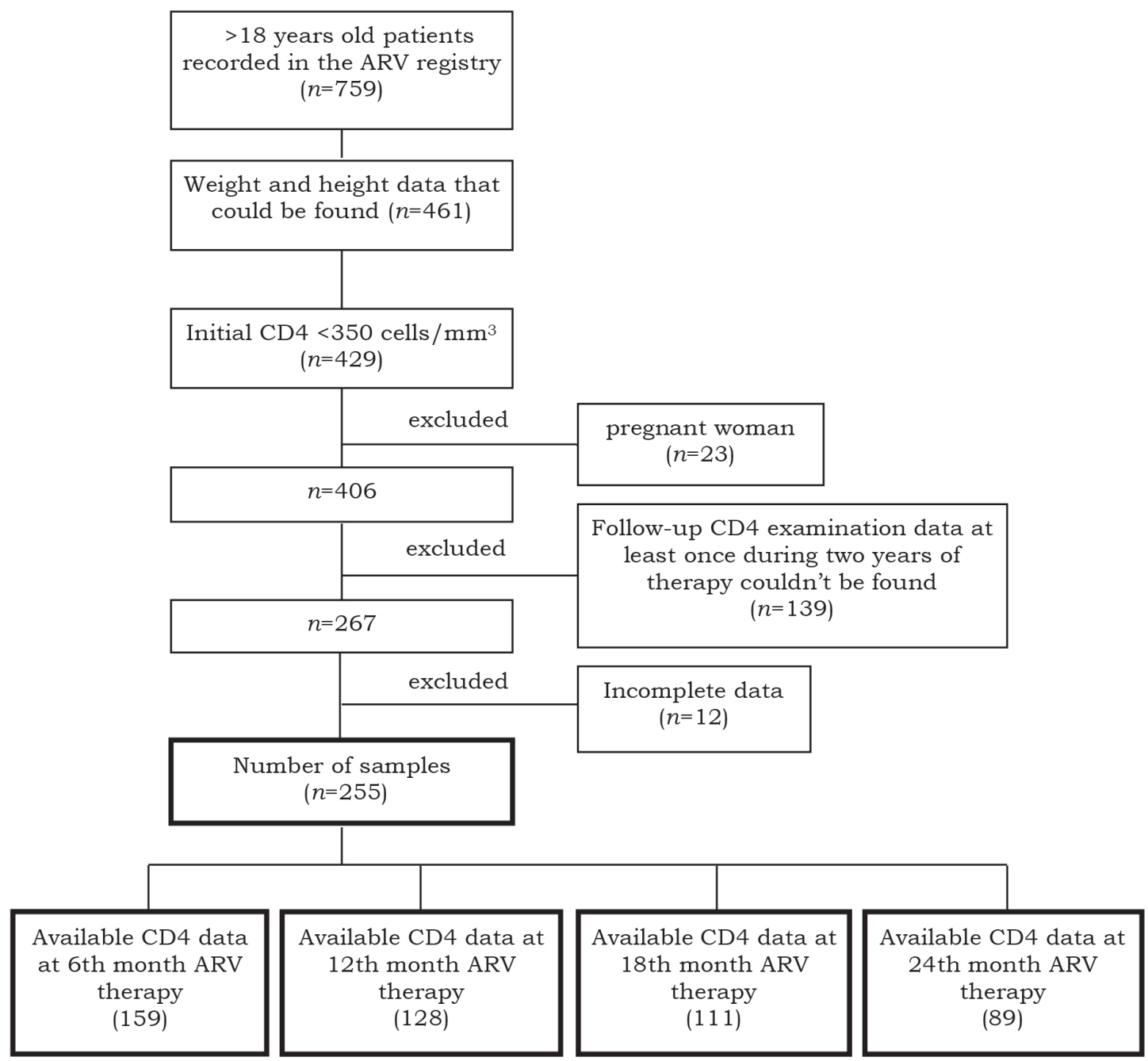

Figure 1. Sampling flow

all patients with HIV-AIDS who had undergone ARV therapy, recorded in the ARV registry and medical records at Dr. Sardjito Hospital from January 2014 to December 2016. The inclusion criteria were $>18$ years old, first time on ARV therapy at Dr. Sardjito Hospital from January 2014 until December 2016 or referral patients with complete medical records, available weight and height data at the beginning of ARV therapy, and CD4 cell count of $<350$ cells $/ \mathrm{mm}^{3}$. The subject exclusion criteria were pregnant at the beginning of ARV therapy, no CD4 examination data available during ARV therapy and any incomplete data. A total of 255 subjects were included in this study. The number of patients that could be analysed in the $6^{\text {th }}, 12^{\text {th }}, 18^{\text {th }}$, and $24^{\text {th }}$ months of ARV therapy were 159 , 128,111 , and 89 subjects, respectively (Figure 1).

\section{Data collection}

Data were collected by recording the data from medical records and ARV registry at Dr. Sardjito Hospital from January to April 2019. Data were recorded in 
the data collection form according to the variables required. Nutritional status, determined by BMI, was an independent variable. BMI status was categorised based on the World Health Organization (WHO) Asia Pacific criteria. Underweight was defined as BMI <18.5 $\mathrm{kg} / \mathrm{m}^{2}$, normal as BMI $18.5-22.9 \mathrm{~kg} /$ $\mathrm{m}^{2}$, overweight as BMI $23-24.9 \mathrm{~kg} / \mathrm{m}^{2}$, and pre-obese as BMI $25-29.9 \mathrm{~kg} / \mathrm{m}^{2}$. The other independent variables were demographic factors (age, education, sex, and occupation), clinical factors [the type of ARV: Nucleoside reverse transcriptase inhibitors (NRTI) and non-nucleoside reverse transcriptase inhibitors (NNRTI), initial CD4 cell count, clinical stage, and co-infection tuberculosis], and regularity of treatment. The dependent variables were the changes in CD4 cell count at the $6^{\text {th }}, 12^{\text {th }}, 18^{\text {th }}$, and $24^{\text {th }}$ months of ARV therapy.

\section{Data analysis}

We conducted data analysis using STATA/IC 13.1. Bivariate data analysis was done using simple linear regression to identify independent predictors of CD4 change at all time points. Multivariate analysis was done using multiple linear regression. Variables included in the analysis were BMI and variables that had a $p$-value of $<0.25$ in the bivariate analysis. The best model was selected by looking at the smallest Bayesian Information Criterion (BIC) value. The level of significance was set at a $p$-value of less than 0.05 and $95 \%$ confidence interval (CI). Multi-collinearity for independent variables was checked before multivariate analysis.

\section{Ethical approval}

Ethical approval was obtained from the Medical and Health Ethics and Research Committee of the Faculty of Medicine, Public Health and Nursing, Universitas
Gadjah Mada (KE/FK/0046/EC/2019). As this study only used secondary data and did not conduct any interviews with HIV-AIDS patients, therefore, it did not require any consent.

\section{RESULTS}

\section{Baseline characteristics}

There were 255 subjects included in this study. A total of 201 (78.82\%) were males with a median age of 31 years old. The median for BMI was $20.07 \mathrm{~kg} / \mathrm{m}^{2}$. Most of them were in normal BMI (52.55\%), started ARV therapy at $<40$ years old (77.25\%), had higher education level (83.53\%), and had a job (72.94\%).

Most of the patients used Tenofovir (TDF) (84.71\%) and Efavirenz (90.59\%) as the type of ARV. The median initial CD4 cell count was 102 cells $/ \mathrm{mm}^{3}$. Most patients had an initial CD4 cell count of $<200$ cells $/ \mathrm{mm}^{3}$ (68.63\%). The number of patients who started therapy with high (3 and 4) and low (1 and 2) clinical stages were relatively the same. There were 58 patients $(22.75 \%)$ who had tuberculosis co-infection. The number of patients who sought treatment regularly decreased every six months. At the 24th month of ARV therapy, there were 154 patients (60.39\%) who still routinely sought treatment (Table 1).

\section{Immune response recovery}

On the 6th, 12th, 18th, and 24th months of ARV therapy, the increase in CD4 cell counts from the start of therapy were 109 cells $/ \mathrm{mm}^{3}, 115$ cells $/ \mathrm{mm}^{3}$, 135 cells $/ \mathrm{mm}^{3}$, and 148 cells $/ \mathrm{mm}^{3}$, respectively. Graphs of CD4 cell count increase by nutritional status showed that in the 18th and 24th months of ARV therapy, normal weight, overweight, and pre-obese patients had higher CD4 cell count increases than underweight patients (Figure 2). 
Table 1. Characteristics of HIV-AIDS patients at the first time of therapy

\begin{tabular}{|c|c|}
\hline Characteristics & $n(\%)$ \\
\hline \multicolumn{2}{|l|}{ BMI } \\
\hline Underweight & 75 (29.4) \\
\hline Normal & $134(52.6)$ \\
\hline Overweight & $25(9.8)$ \\
\hline Pre-obese & $21(8.2)$ \\
\hline \multirow{2}{*}{\multicolumn{2}{|c|}{$\begin{array}{l}\text { Median : } 20.07 \mathrm{~kg} / \mathrm{m}^{2} \\
\text { Min-Max : } 12.12-29.75 \mathrm{~kg} / \mathrm{m}^{2}\end{array}$}} \\
\hline & \\
\hline \multicolumn{2}{|l|}{ Age in years } \\
\hline$\geq 40$ & $58(22.8)$ \\
\hline$<40$ & $197(77.3)$ \\
\hline \multicolumn{2}{|l|}{ Median : 31} \\
\hline \multicolumn{2}{|l|}{ Min-Max : $18-60$} \\
\hline \multicolumn{2}{|l|}{ Sex } \\
\hline Male & $201(78.8)$ \\
\hline Female & $54(21.2)$ \\
\hline \multicolumn{2}{|l|}{ Education } \\
\hline Low & $42(16.5)$ \\
\hline High & $213(83.5)$ \\
\hline \multicolumn{2}{|l|}{ Occupation status } \\
\hline Unemployed & $69(27.1)$ \\
\hline Employed & $186(72.9)$ \\
\hline \multicolumn{2}{|l|}{ ARV NRTI types } \\
\hline Zidovudine (AZT) & 39 (15.3) \\
\hline Tenofovir (TDF) & $216(84.7)$ \\
\hline \multicolumn{2}{|l|}{ ARV NNRTI types } \\
\hline Neviraprine (NVP) & $24(9.4)$ \\
\hline Efavirenz (EFV) & $231(90.6)$ \\
\hline \multicolumn{2}{|l|}{ Initial CD4 cell count } \\
\hline$\leq 200$ cells $/ \mathrm{mm}^{3}$ & $175(68.6)$ \\
\hline $200-349$ cells $/ \mathrm{mm}^{3}$ & $80(31.2)$ \\
\hline \multicolumn{2}{|l|}{ Median : 102 cells $/ \mathrm{mm}^{3}$} \\
\hline \multicolumn{2}{|l|}{ Min-Max : $1-349$ cells $/ \mathrm{mm}^{3}$} \\
\hline \multicolumn{2}{|l|}{ Clinical stage } \\
\hline High (3 and 4$)$ & $120(47.1)$ \\
\hline Low (1 and 2$)$ & $135(52.9)$ \\
\hline \multicolumn{2}{|l|}{ Tuberculosis co-infection } \\
\hline No & $58(22.8)$ \\
\hline Yes & $197(77.3)$ \\
\hline \multicolumn{2}{|l|}{ Treatment regularity } \\
\hline \multicolumn{2}{|l|}{$6^{\text {th }}$ month } \\
\hline Irregular & $34(13.3)$ \\
\hline Regular & $221(86.7)$ \\
\hline \multicolumn{2}{|l|}{$12^{\text {th }}$ month } \\
\hline Irregular & $68(26.7)$ \\
\hline Regular & $187(73.3)$ \\
\hline \multicolumn{2}{|l|}{$18^{\text {th }}$ month } \\
\hline Irregular & 83 (32.6) \\
\hline Regular & $172(67.5)$ \\
\hline \multicolumn{2}{|l|}{$24^{\text {th }}$ month } \\
\hline Irregular & $101(39.6)$ \\
\hline Regular & $\begin{array}{l}101(39.0) \\
154(60.4)\end{array}$ \\
\hline
\end{tabular}




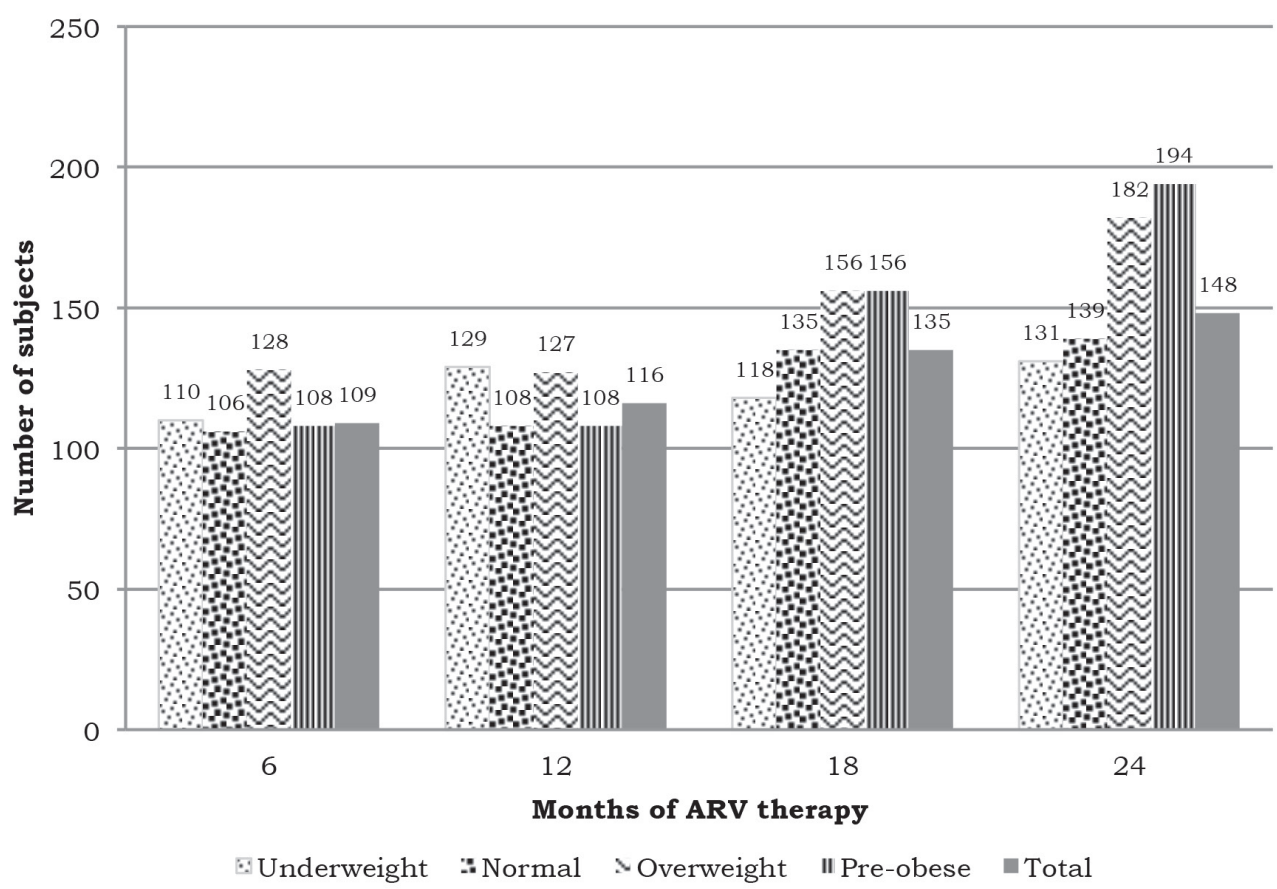

Figure 2. CD 4 cell count increase at $6^{\text {th }}, 12^{\text {th }}, 18^{\text {th }}$, and $24^{\text {th }}$ months of ARV therapy by BMI status

Factors related to immune response recovery at 6 th, 12 th, 18 th and 24 th months of ARV therapy

Immune response recovery at 6 months

There were no significant factors related to the immune response recovery at the $6^{\text {th }}$ month of ARV therapy, but CD4 cell counts of overweight patients increased 16.77 cells $/ \mathrm{mm}^{3}(p=0.478)$ compared to underweight patients (Table 2).

Immune response recovery at 12 months Treatment regularity was the only independent variable that was significantly related to the immune response recovery at the $12^{\text {th }}$ month of ARV therapy. CD4 cell counts of patients who did regular treatment increased 66.88 cells $/ \mathrm{mm}^{3}(p=0.003)$ compared to patients who did not undertake regular treatment. CD4 cell counts of overweight patients decreased 9.638 cells $/ \mathrm{mm}^{3}$ $(p=0.807)$ compared to underweight patients (Table 3).

Immune response recovery at 18 months NRTI type of ARV and treatment regularity were independent variables that were significantly related to immune response recovery at the $18^{\text {th }}$ month of ARV therapy. CD4 cell counts of patients who used TDF increased 74.83 cells/ $\mathrm{mm}^{3}(p=0.001)$ compared to Zidovudine (AZT). CD4 cell counts of patients who did regular treatment increased by 70.07 cells $/ \mathrm{mm}^{3}(p=0.005)$ compared to patients who did not undertake regular treatment. In comparison to underweight patients, CD4 cell counts of overweight and pre-obese patients were higher. The increase in CD4 cell count was 39.55 cells $/ \mathrm{mm}^{3}(p=0.274)$ among overweight patients and 33.38 cells $/ \mathrm{mm}^{3}(p=0.302)$ among pre-obese patients (Table 3 ). 


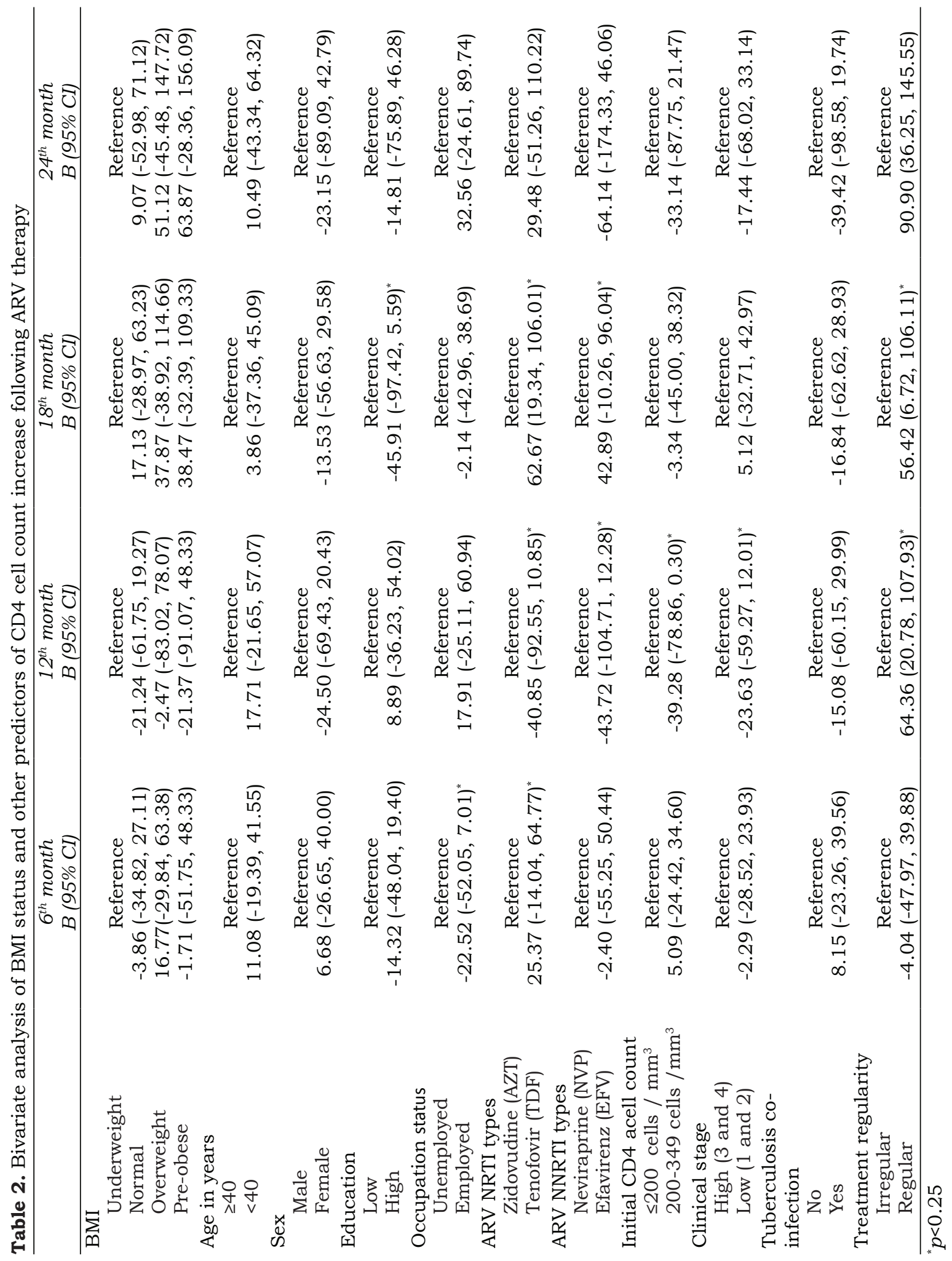


Immune response recovery at 24 months Treatment regularity was the only independent variable that was significantly related to immune response recovery at the $24^{\text {th }}$ month of ARV therapy. CD4 cell counts of patients who did regular treatment increased by 85.77 cells $/ \mathrm{mm}^{3}$ ( $\left.p=0.003\right)$ compared to patients who did not undertake regular treatment. CD4 cell counts of overweight patients increased 38.14 cells $/ \mathrm{mm}^{3}$ $(p=0.409)$ compared to underweight patients. Also, CD4 cell counts of preobese patients increased 49.36 cells/ $\mathrm{mm}^{3}(p=0.265)$ compared to underweight patients (Table 3 ).

\section{DISCUSSION}

BMI did not have a significant relationship to immune response recovery at the first time of ARV therapy. This means that across all nutritional status, immune response recovery is the same. But, on the $18^{\text {th }}$ and $24^{\text {th }}$ months of ARV therapy, the increase in CD4 cell counts of underweight patients was the lowest compared to the others. This is in line with the study by Hussen, Belachew \& Hussien (2016), which showed that malnutrition was associated with lower CD4 recovery, although there was no significant relationship statistically.

This can be explained by a previous finding that undernourished individuals experience a reduction in leukotrienes, which promote leukocyte accumulation and enhance macrophage phagocytosis. Such a condition will negatively affect the host's ability to kill microbial, fungal, and parasitic agents (Bresnahan \& Tanumihardjo, 2014). A study by Sudfeld et al. (2013) showed that low baseline BMI was associated with an increased incidence of oral thrush, pneumonia, and tuberculosis. It showed that the immune response gets worse in

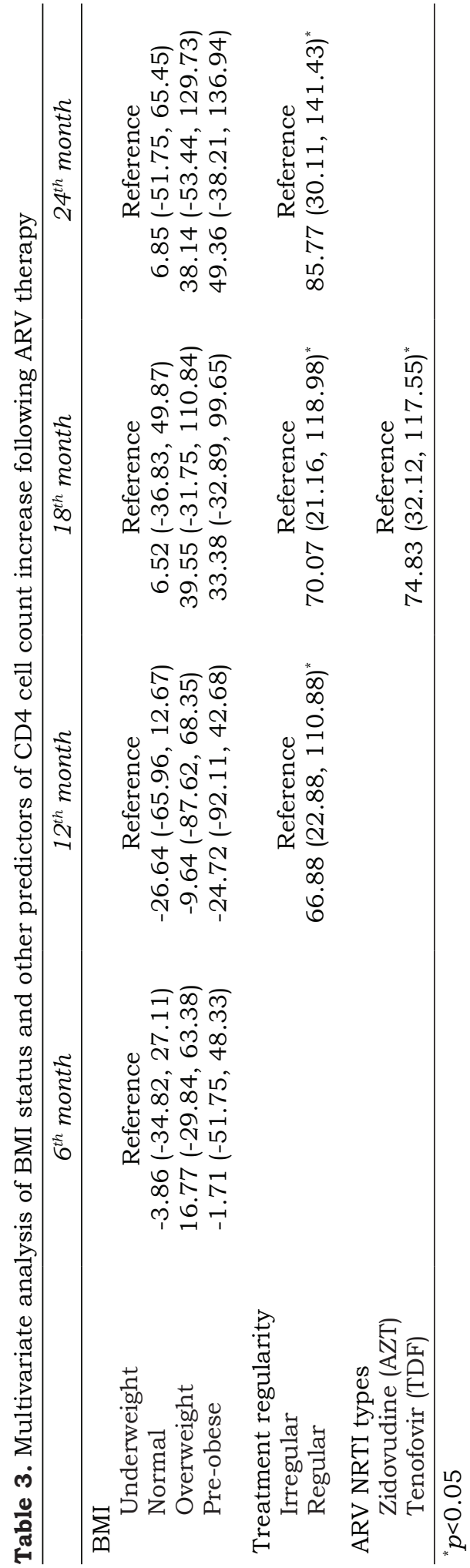


HIV patients with low baseline BMI, so the incidence of opportunistic infections increases.

Underweightusuallyoccurs as a result of protein-energy and micronutrient malnutrition. Although this study did not specify the role of micronutrients, we can explain that lack of micronutrients at the first time of ARV therapy maybe the barrier of immune response recovery. There were some micronutrients, including vitamins $\mathrm{A}, \mathrm{D}, \mathrm{C}, \mathrm{E}, \mathrm{B} 6$, and B12, folate, zinc, iron, copper, and selenium, which play vital roles at every stage of the immune response. Adequate amounts of micronutrients are essential to ensure proper functioning of the immune cells. It is well established that overt micronutrient deficiencies can adversely affect the immune system and predispose individuals to infections (Gombart, Pierre \& Maggini, 2020).

On the other hand, we could tell that there was enough protein-energy and also micronutrients in normal, overweight, and obese patients at the first time of ARV therapy. So, the increase in CD4 cells remained better than underweight patients. The CD4 cell counts in overweight and pre-obese patients showed a higher increase, especially in the 18th and 24th months of ARV therapy. The study by Palermo et al (2011) showed that overweight and obese patients had higher CD4 cell counts increases at 96th and 144th weeks of ARV therapy, but not in the 48th week. Research by Blashill et al. (2013) in male HIV patients who had sex with men showed that HIV-positive men who were overweight $\left(>25 \mathrm{~kg} / \mathrm{m}^{2}\right)$ had a higher CD4 cell count than normalweight men. Research conducted by Koethe et al. (2015a) also showed that compared with a BMI of $22 \mathrm{~kg} / \mathrm{m}^{2}$, a BMI $30 \mathrm{~kg} / \mathrm{m}^{2}$ was associated with higher CD4 cell counts at the 12th month of ARV therapy, both in women and men infected with HIV.

The latest trend showed an increase of overweight and obesity in people with HIV-AIDS (Koethe et al., 2015b). In HIV-AIDS patients with a higher BMI, several studies showed an interaction between adipose tissue in the body with immune system. Adipose tissue represents one of the largest organs in the body and comprises of various types of cells with diverse energy storage, metabolic regulation, neuroendocrine, and immunological functions. HIV infection and ARV can cause alterations to adipose tissue distribution and biology, with the effects on cytokines and hormone expression, lipid storage, and the composition of adipose-resident immune cell populations. There is a positive relationship between adipose tissue and lymphocyte proliferation, CD4 cell counts, and lymphocyte activation (Koethe, Hulgan \& Niswender, 2013a).

Adipose tissue in the body also acts as an endocrine gland. It secretes cytokine-like hormones commonly called adipokines. One of the adipokines that play an important immune function is leptin. Leptin regulates energy homeostasis, neuroendocrine function, metabolism, immune function, and other systems. Leptin regulates innate and adaptive immune responses. Leptin in the hypothalamus is bound by receptors in $\mathrm{T}$ cells. It clears the connection between adipose cells and the immune system. Research on mice that have lost their leptin encoding genes showed a disruption in T helper-1/Th1 cells (Park \& Ahima, 2015; Francisco et al., 2018).

Research by Koethe et al. (2013b) showed that higher median leptin in HIV-AIDS patients on ARV therapy is also in line with a higher BMI. Research by Al-Fadhli et al. (2012) showed that there is a positive correlation between the amount of leptin in the body of an HIV-infected person and CD4 cell count. 
However, some other studies showed different results. Research by CrumCianflone et al. (2011) showed that obese HIV patients have lower CD4 cell counts compared with normal weight patients. A recent study by Tiliscan et al. (2015) also found that there was no significant relationship between the amount of leptin in the body and the immune system in HIV patients on ARV therapy.

This also can be explained by the role of the metabolism process in patients with higher BMIs. Lipid metabolism also plays a role in the immune response. $\mathrm{T}$ lymphocyte proliferation is highly dependent on glycolysis and lipogenesis. The activation of $T$ cells requires glycolysis to support their proliferation. $\mathrm{T}$ cell proliferation is highly dependent on mitochondria respiration. It is speculated that $\mathrm{T}$ lymphocyte requires lipids during proliferation to maintain and remodel cell membranes (Ganeshan \& Chawla, 2014; Hubler \& Kennedy, 2016).

The $<40$ years old patients always showed a higher increase in CD4 cell counts, although not significantly. Other studies have shown the association between younger age on ARV therapy and improved immune response. Research conducted by Montarroyos et al. (2014) and Hunt et al. (2015) showed that $\geq 40$ years old patients had a lower CD4 cell count increase than $<40$ years old patients. Gender, education, and occupation did not show a significant relationship with CD4 cell count increase. It is because all patients at Dr. Sardjito Hospital had the same opportunity to get ARV therapy.

The results showed that variables that have a significant relation with CD4 cell count increase were TDF type ARV and treatment regularity. TDF is an ARV regimen recommended by WHO. Some studies showed that TDF increases immune response more than AZT. A retrospective cohort study conducted by
Ayele, Jarso \& Mamo (2017) for two years in Ethiopia showed that the TDF regimen had better immune improvements. A prospective study conducted by Badii $\&$ Buabeng (2018) in Ghana also showed that patients taking TDF ARVs had a higher CD4 cell increase compared to those using ZDV.

The regularity of treatment is important in improving the immune response of HIV-AIDS patients on ARV therapy. Research by Abrogoua et al. (2012) showed that adherence was the most significant factor related to immune response compared to initial CD4 cell count for two years of antiretroviral therapy. Research by Annison, Dompreh \& Adu-Sarkodie (2013) also showed that the CD4 cell count increase of patients who were adherent to treatment was higher than those who were not adherent to treatment.

Regularity of treatment was the main factor in ARV therapy. The higher proportion of patients seeking treatment regularly were patients with tuberculosis co-infection. So, the increase in CD4 cell counts was also higher in these patients than patients without tuberculosis coinfection. Healthy diet and lifestyles during therapy are also possible factors that can improve the immune response of HIV patients on ARV therapy. But, we did not measure this in this study.

The limitation of this study was the incomplete CD4 examination data, resulting in a different number of subjects analysed and the inability to conduct further sub-sample analysis. We did not have complete weight and height data over time, so we could not look at the relationship between nutritional status and immune response over time.

\section{CONCLUSION}

This study showed that higher BMI levels, the use of TDF ARVs, and regular treatment resulted in a higher increase 
in CD4 cell counts. Understanding the predicting factors for the increase in CD4 cell counts could benefit in bettering HIV and ARV services.

\section{Acknowledgement}

The authors would like to give thanks to the Magister of Public Health, Faculty of Medicine, Public Health, and Nursing, Universitas Gadjah Mada which had given support to this study. Thanks to Dr. Sardjito Hospital for permitting us to collect the research data and also to the Board for Development and Empowerment Human Resources of Health, Ministry of Health of Indonesia, that has provided funding for this research.

\section{Authors' contributions}

IPA, conceptualised and designed the study, collected and analysed the data, prepared the draft of the manuscript; YWS, advised on data analysis and interpretation, and reviewed the manuscript; NAK, advised on data analysis and interpretation, and reviewed the manuscript.

\section{Conflict of interest}

The authors declare no conflict of interest.

\section{References}

Abrogoua DP, Kablan BJ, Thierry BA, Aulagner G, N'Guessan K \& Zohore C (2012). Assessment of the impact of adherence and other predictors during HAART on various CD4 cell responses in resource-limited settings. Patient Prefer Adherence 6:227-237.

Al-Fadhli M, Saraya M, Qasem J, Azizieh F, Shahab S \& Raghupathy (2012). Relationship between leptin levels and suppressed CD4 counts in HIV patients. Med Princ Pract 22(1):54-58.

Alwarawrah Y, Kiernan K \& Maclver NJ (2018). Changes in nutritional status impact immune cell metabolism and function. Front Immunol 9(1055):1-14.

Annison L, Dompreh A \& Adu-Sarkodie Y (2013). The immunological response of HIV-positive patients initiating HAART at the Komfo Anokye Teaching Hospital, Kumasi, Ghana. Ghana Med J 47(4):164-170.

Ayele T, Jarso H \& Mamo G (2017). Immunological outcomes of tenofovir versus zidovudine-based regimens among people living with HIV/AIDS: a two years retrospective cohort study. AIDS Res Ther 14(1):1-11.
Badii VS \& Buabeng KO (2018). Tenofovir-based highly active antiretroviral therapy is associated with superior $\mathrm{CD} 4 \mathrm{t}$ cells repopulation compared to zidovudine-based HAART in HIV 1 infected adults. Int $J$ Chronic Dis 2018:1-8.

Blashill AJ, Mayyer KH, Crane HM, Grasso C \& Safren SA (2013). Body mass index, immune status, and virological control in HIV-infected men who have sex with men. J Int Assoc Provid AIDS Care 12(5):319-324.

Bresnahan KA \& Tanumihardjo SA (2014). Undernutrition, the acute phase response to infection, and its effect on micronutrient status indicators. Adv Nutr 5(6):702-711.

Crum-Cianflone NF, Roediger M, Eberly LE, Vyas $\mathrm{K}$, Landrum ML, Ganesan A, Weintrob A, Johnson E \& Agan BK (2011). Impact of weight on immune cell counts among HIV-infected persons. Clin Vaccine Immunol 18(6):940-946.

Dravid MN, Kulkarni SD, Khadse R \& Adchitre HR (2011). Two years CD4 count follow-up of rural patients on antiretroviral therapy: a study in government hospital. Indian $J$ Sex Transm Dis AIDS 32(1):59-60.

Duggal S, Chugh TD \& Duggal AK (2012). HIV and malnutrition : effects on immune system. Clin Dev Immunol 2012:1-7.

Francisco V, Pino J, Capos-Cabaleiro V, RuizFernandez C, Mera A, Gonzalez-Gay MA, Gomez R \& Gualillo O (2018). Obesity, fat Mass and immune system: role for leptin. Front Physiol 9:1-20.

Ganeshan K \& Chawla A (2014). Metabolic rehulation of immune responses. Annu Rev Imunol 32:609-634.

Gombart AF, Pierre A \& Maggini S (2020). A review of micronutriants and the immune systemworking in harmony to reduce the risk of infection. Nutrients 12(236):1-41.

Hubler MJ \& Kennedy AJ (2016). Role of lipids in the metabolism and activation immune cells. $J$ Nutr Biochem 34:1-7.

Hunt K, Mondal P, Konrad S, Skinner S, Gartner K \& Lim HJ (2015). Identifying factors associated with changes in CD4+ count in HIV-infected adults in Saskatoon, Saskatchewan. Can $J$ Infect Dis Med Microbiol 26(4):207-211.

Hussen S, Belachew T \& Hussien N (2016). Nutritional status and its effect on treatment outcome among HIV infected clients receiving HAART in Ethiopia: a cohort study. AIDS Research and Therapy. BioMed Central 13(32):1-8. 
Koethe JR, Jenkins CA, Shepherd BE, Stinnette SE \& Sterling TR (2011). An optimal body mass index range associated with improved immune reconstitution among HIV-infected adults initiating antiretroviral therapy. HIV. AIDS 53:952-960.

Koethe JR, Hulgan T \& Niswender K (2013a). Adipose Tissue and immune function: a review of evidence relevant to HIV infection. J of Infect Dis 208(8):1194-1201.

Koethe JR, Dee K, Bian A, Shintani A, Turner M, Bebawy S, Sterling T \& Hulgan T (2013b). Circulating interleukin-6, soluble CD14, and other inflammation biomarker levels differ between obese and nonobese HIV-infected adults on antiretroviral therapy. AIDS Res Hum Retroviruses 29(7):1019-1025.

Koethe JR, Jenkins CA, Lau B, Shepherd BE, Silverberg MJ, Brown TT, Blashill AJ, Anema A, WIllig A, Stinette S, Napravnik S, Gill J, Crane HM \& Sterling TR (2015a). Body mass index and early CD4+ T-cell recovery among adults initiating antiretroviral therapy in North America, 1998-2010. HIV Med 16(9):572-277.

Koethe JR, Jenkins C A, Lau B, Shepherd BE, Justice AC, Tate JP, Buchacz K, Napravnik S, Mayor AM, Horberg MA, Blashill AJ, Willig A, Wester CW, Silverberg MJ, Gill J, Thorne JE, Klein M, Eron JJ, Kitahata MM, Sterling TR \& Moore RD (2015b). Rising obesity prevalence and weight gain among adults starting antiretroviral therapy in the United States and Canada. AIDS Res Hum Retroviruses 32(1):5058.

Makvandi-Nejad S (2016) Human Immunodeficiency Virus ( HIV). Oxford.

Montarroyos UR, Miranda-Filho DB, Cesar CC, Souza WV, Lacerda HR, Albuquerque MFPM, Aguiar MF \& Ximenes RAA (2014). Factors related to changes in cd4+ $t$-cell counts over time in patients living with HIV/AIDS: A Multilevel Analysis. PLOS ONE 9(2):1-9.
Palermo B, Bosch RJ, Bennet K \& Jacobson JM (2011). Body mass index and CD4+ T-lympocyte in HIV Infected men with viral suppression on antiretroviral therapy. HIV Clin Trials 12(4):222-227.

Park H \& Ahima RS (2015). Physiology of leptin: energy homeostatis, neuroendovrine function and metabolism. Metabolism 64(1):24-34.

Sharma A, Hoover DR, Shi Q, Gustafon D, Plankey WM, Herwhow RC, Tien PC, Golub ET \& Anastos K (2015). Relationship between body mass index and mortality in HIV-infected HAART users in the women' s interagency HIV study. PLoS ONE 10(2):1-16.

Sudfeld CR, Isanaka S, Mugusi FM, Aboud S, Wang M, Chalamila GE, GIovannuci WL \& Fawzi WW (2013). Weight change at 1 mo of antiretroviral therapy and its association with subsequent mortality, morbidity, and CD4 T cell reconstitution in a Tanzanian HIV-infected adult cohort 1 - 3'. Am J Clin Nutr 97(3):12781287.

Tiliscan C, Arama V, Mihailescu R, Munteanu DI, Streinu-Cercel A, Ion DA, Radulescu MA, Popescu C, Lobodan AE, Negru AR \& Arama SS (2015). Leptin expression in HIV-infected patients during antiretroviral therapy. Germs 5(3): 92-98.

Walker B \& Mcmichael A (2012). The T-Cell response to HIV. Cold Spring Harb Prespect Med 2(a0070554):1-19. 